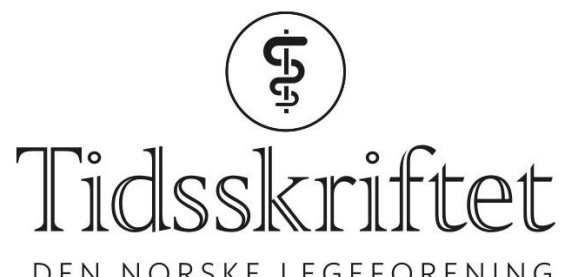

\title{
SGLT2-hemmere gir mindre hjertesykdom ved diabetes
}

FRA ANDRE TIDSSKRIFTER

ØYVIND STOPLE SIVERTSEN

Tidsskriftet

Bruk av SGLT2-hemmere ved type 2-diabetes er assosiert med lavere risiko for hjertesykdom og hjertedød. Det viser en nordisk studie med norsk førsteforfatter.

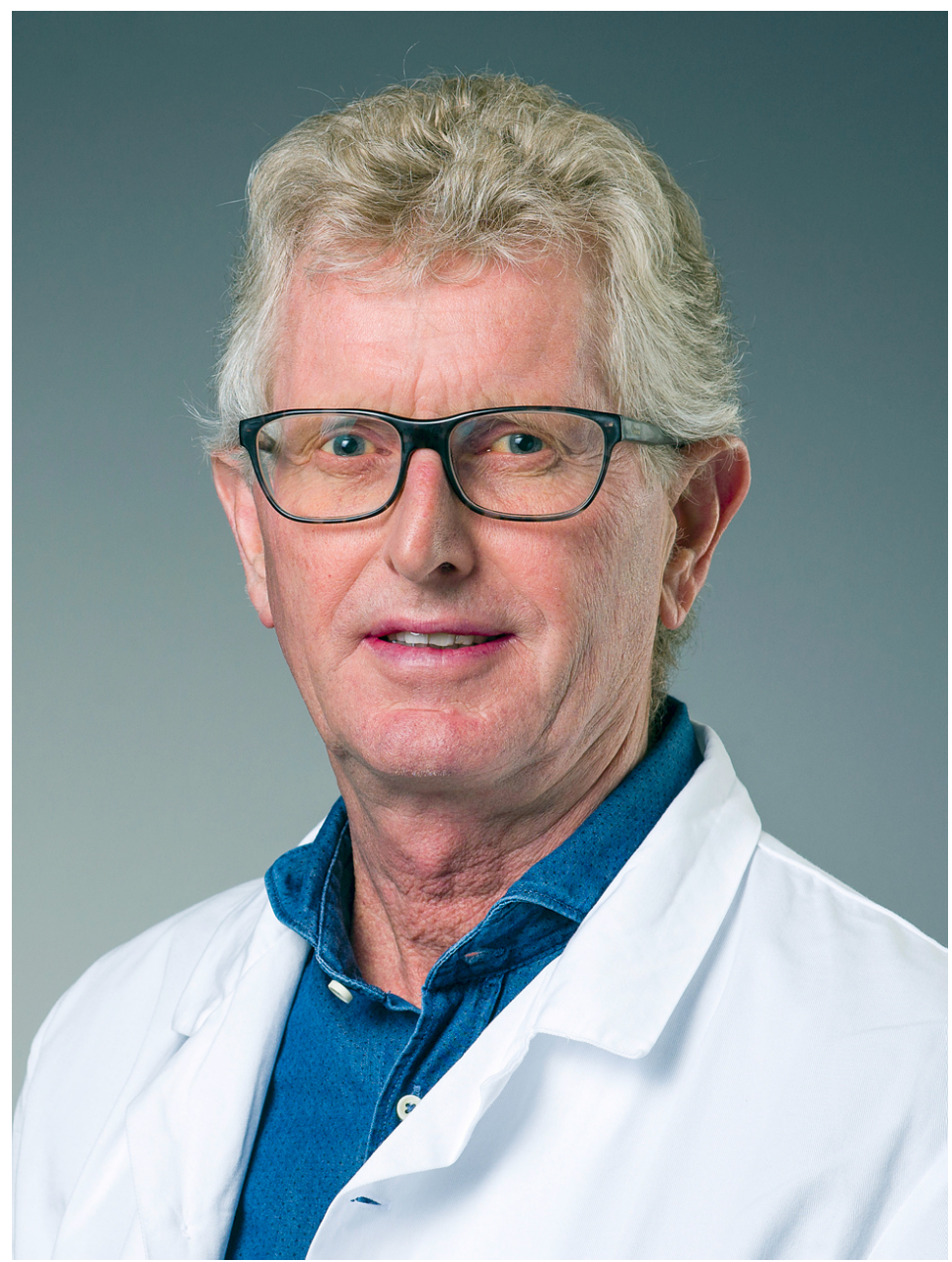

Foto: Øystein H. Horgmo, Universitetet i Oslo

SGLT2-hemmere er selektive, potente og reversible hemmere av natriumglukosekotransportør 2. De uttrykkes selektivt i nyrene og reabsorberer glukose fra 
glomerulærfiltratet til sirkulasjonen. På den måten reduserer de nyrenes reabsorpsjon av glukose og fører til renal glukoseutskilling.

I en studie som nylig er publisert i The Lancet Diabetes \& Endocrinology, ble data om flere enn 90 ooo pasienter i Norge, Sverige og Danmark hentet inn fra reseptregistre,

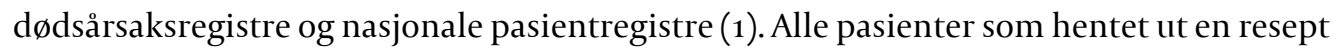
på glukosesenkende medisin i perioden 2012-15, ble fulgt opp ut 2015 og delt inn i to grupper: nye SGLT2-brukere og nye brukere av andre perorale antidiabetika. Sammenlignet med dem som brukte andre antidiabetika hadde brukere av SGLT2-hemmere lavere risiko for hjertesvikt og total dødelighet, og færre døde av hjerte- og karsykdom.

- Denne studien viser at bruken av SGLT2-hemmere i vanlig klinisk praksis har en gunstig tilleggseffekt, sier Kåre I. Birkeland, professor og overlege ved Oslo universitetssykehus og studiens førsteforfatter. Hanne Løvdal Gulseth, som arbeider ved Avdeling for endokrinologi, sykelig overvekt og forebyggende medisin ved Oslo universitetssykehus, er medforfatter.

- Vi mener dette er interessante data, også fordi de fremkommer ved bruk av nasjonale registre i flere land. I Norden har vi mange gode registre og har derfor muligheten til å gjennomføre registerstudier som dekker hele befolkningen. Det er interessant å se hvor konsistent funnene er i alle landene vi har data fra, sier Birkeland. Resultatene støttes av to randomiserte, placebokontrollerte studier (2).

- Observasjonsstudier kan aldri erstatte gode prospektive, randomiserte, kontrollerte kliniske studier, men kan supplere slike studier ved at de inkluderer et bredere spekter av pasienter, sier Birkeland.

\section{LITTERATUR:}

1. Birkeland KI, Jørgensen ME, Carstensen B et al. Cardiovascular mortality and morbidity in patients with type 2 diabetes following initiation of sodium-glucose co-transporter-2 inhibitors versus other glucose-lowering drugs (CVD-REAL Nordic): a multinational observational analysis. Lancet Diabetes Endocrinol 2017; 5: 709-17. [PubMed][CrossRef]

2. Neal B, Perkovic V, Mahaffey KW et al. Canagliflozin and cardiovascular and renal events in type 2 Diabetes. N Engl J Med 2017; 377: 644 - 57. [PubMed][CrossRef]

Publisert: 13. november 2017. Tidsskr Nor Legeforen. DOI: 10.4045/tidsskr.17.0812

(C) Tidsskrift for Den norske legeforening 2020. Lastet ned fra tidsskriftet.no 